\title{
4 Gilbert and Sullivan and the railway
}

Of COURSE MUSIC hall was not the only form of music theatre in the nineteenth century. The operettas of Gilbert and Sullivan were hugely popular, not only in the Savoy Theatre but across the country at a time when amateur operatic societies were springing up all over the UK. ${ }^{1}$ The producer Richard D'Oyly Carte brought together the dramatist W S Gilbert (1836-1911) and the composer Arthur Sullivan (1842-1900) and nurtured their collaboration. Together they created 14 operettas, the best known being The Mikado, The Pirates of Penzance and HMS Pinafore. In 1881 D'Oyly Carte built the Savoy Theatre and founded the D'Oyly Carte Opera Company specifically to perform their works. The operettas embraced social and political satire by the means of ridiculous plots; the words were satirical and the tunes were catchy.

The railways were something close to Gilbert's heart. In 1897 he wrote to The Times to complain about the lateness of the trains on the line between Watford and Euston during the holiday season. ${ }^{2}$ The letter famously ends with the words "To the question, "What has caused the train to be so late?" the officials reply, "It is Saturday" - as who should say, "It is an earthquake."”3

Gilbert is similarly critical in three of the references he makes to the railways in his operettas. 'The Lord Chancellor's nightmare song' from Iolanthe (1882) includes a 'very small second class carriage' as a feature of the nightmare. Second class carriages during the 1880s would have been quite uncomfortable; the lighting would have been poor and very few carriages would have been heated before 1900. It should be noted, however, that by 1882 few railway companies offered second class travel - this intermediate class had been largely abandoned leaving a choice between the expensive first class and the cheap, but overcrowded, third-class carriages. 
For you dream you are crossing the channel, and tossing

About in a steamer from Harwich,

Which is something between a large bathing machine

And a very small second class carriage,

And you're giving a treat (penny ice and cold meat)

To a party of friends and relations,

They're a ravenous horde, and they all come aboard

At Sloane Square and South Kensington stations.

A further critical reference to carriage classes is made in Trial by Jury in "The judge's song'.

In Westminster Hall I danced a dance,

Like a semi-despondent fury;

For I thought I never should hit on a chance

Of addressing a British jury -

But I soon got tired of third-class journeys,

And dinners of bread and water;

So I fell in love with a rich attorney's

Elderly, ugly daughter.

In the 1885 operetta The Mikado, the Mikado's diatribe which opens with the words 'A more humane Mikado never' goes on to prescribe punishments to fit various crimes. The fourth verse announces that:

The idiot who, in railway carriages,

Scribbles on window-panes,

We only suffer

To ride on a buffer

In Parliamentary trains.

Parliamentary trains originated in 1841 following a terrible train accident at Sonning, near Reading which resulted in the deaths of eight people who were travelling in low-sided open wagons. This led to a Board of Trade enquiry into the conveyance of third-class passengers. As a result Gladstone's 1844 Railway Regulation Act ensured the provision of at least one train a day each way at a speed of not less than 12 miles an hour including stops, which were to be made at all stations, and of carriages protected from the weather and provided with seats; for all which luxuries not more than a penny a mile might be charged.' In return the railway companies became exempt of the 5\% passenger tax which 
was normally levied on all fares. In 1844 the minimum speed of 12 miles per hour was relatively fast, even the best horse-drawn carriages could go no faster than $10 \mathrm{mph}$. However, by the 1870s, the minimum speed of Parliamentary trains, as they came to be known, was considered to be very slow. Nevertheless, they stimulated the growth of cheap travel and enabled thousands of people to travel who otherwise would not have been able to travel at all. Parliamentary tickets did not disappear for a long time, Bishop's Castle Railway was still issuing tickets marked 'Parliament' in 1935.

\section{The Junction Song}

'The Junction Song' (sometimes known as 'The Railway Song'), 'a cautionary song about an egalitarian railway chairman ${ }^{4}$ is full of references to the railway and had an accompaniment including the sounds of a railway bell, a railway whistle, and some new instrument of music imitating the agreeable sound of a train in motion. ${ }^{.5}$ It is sad to say that the music was never published and it is now lost so performances today either adapt music from other Sullivan scores or use music specially written by more recent composers. The song was sung by the title character of the first work that Gilbert and Sullivan collaborated on Thespis, or The Gods Grown Old - an operatic extravaganza that was premièred in London at the Gaiety Theatre on 26 December 1871. So successful was the Christmas entertainment that it ran into early March the following year. It was advertised as 'An entirely original Grotesque Opera in Two Acts' and included 'much dancing and magnificent scenery and costumes. ${ }^{6}$ It tells the story of the aging Gods on Mount Olympus who decide to leave for a holiday.

We know from contemporary reviews that the orchestration included a railway bell and whistle as well as the sound of a train in motion. In its review, the stage magazine The Era also describes the "ballad... being admirably sung by Mr. J. L. Toole, and furnished with a screaming, whistling, and shouting horns [which] fairly brings the house down. 'The entire company join in the chorus, the music of which admirably expresses the whirl and thunder of a railway train at express speed.' 
'Twas told to me with great compunction,

By one who had discharged with unction

A chairman of directors function

On the North South East West Diddlesex Junction.

Fol diddle, lol diddle, lol lol lay.

The chorus emphasises the rhythmic train-evoking sounds of the rhyming words 'function', 'junction', 'compunction' and 'unction' ending with the rhythmic 'Fol diddle, lol diddle, lol lol lay'.

This could suggest the following mechanical rhythm.

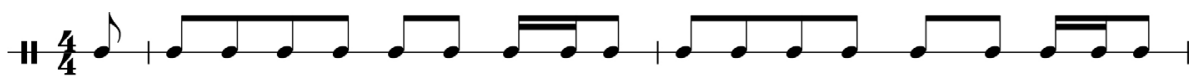

'Twas told to me with great com-punc-tion By one who had dis-charged with unc-tion A
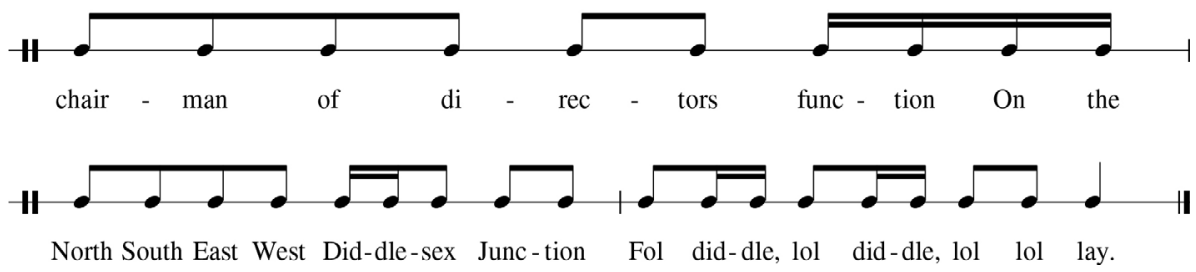


\section{The Junction Song from Thespis.}

I once knew a chap who discharged a function

On the North South East West Diddlesex Junction.

He was conspicuous exceeding,

For his affable ways, and his easy breeding.

Although a chairman of directors,

He was hand in glove with the ticket inspectors.

He tipped the guards with brand new fivers,

And sang little songs to the engine drivers.

\section{Chorus}

"Twas told to me with great compunction,

By one who had discharged with unction

A chairman of directors function

On the North South East West Diddlesex

Junction.

Fol diddle, lol diddle, lol lol lay.

Each Christmas day he gave each stoker

A silver shovel and a golden poker.

He'd button hole flowers for the ticket sorters

And rich Bath-buns for the outside porters.

He'd moun the clerks on his first-class hunters,

And he build little villas for the road-side

shunters,

And if any were fond of pigeon shooting,

He'd ask them down to his place at Tooting.

\section{Chorus.}

In course of time there spread a rumour That he did all this from a sense of humour.

So instead of signalling and stoking,

They gave themselves up to a course of joking.

Whenever they knew that he was riding,

They shunted his train on a lonely siding,

Or stopped all night in the middle of a tunnel,

On the plea that the boiler was a-coming

through the funnel.

\section{Chorus}

If he wished to go to Perth or Stirling, His train through several counties whirling, Would set him down in a fit of larking, At four a.m. in the wilds of Barking. This pleased his whim and seemed to strike it, But the general public did not like it.

The receipts fell, after a few repeatings, And he got it hot at the annual meetings.

\section{Chorus}

He followed out his whim with vigour, The shares went down to a nominal figure.

These are the sad results proceeding From his affable ways and his easy breeding. The line, with its rails and guards and peelers, Was sold for a song to marine store dealers The shareholders are all in the work'us, And he sells pipe-lights in the Regent Circus.

\section{Chorus}

Each of the verses, barring the first, can be fitted to a similar rhythmic pattern using repeated quavers and pairs of semiquavers. The first verse does not fit into this metric pattern probably because it was not intended to be sung, but was delivered in a declamatory parlando (speaking) style. 
Several writers have taken up the idea that the song is about the Duke of Sutherland, referring to him as the Director of the London North Western Railway (LNWR), who had a fondness for trains and reputedly enjoyed riding along on the footplate of his company's engines. ${ }^{9}$ The Duke of Sutherland in 1871, the time that Thespis was written, was George Granville William Sutherland-Leveson-Gower, 3rd Duke of Sutherland (1828 -1892). He did indeed have a great fondness for trains and in 1870 he financed the extension of the Highland Railway line from Golspie to Helmsdale via his own home Dunrobin Castle. In return he received a private station for his castle and the freedom to run his own train on the lines owned by the Highland Railway, having had his own carriages and locomotive built for the purpose. The Duke's enthusiasm for railway building projects and steam technology was welldocumented, but this went together with a 'decided lack of interest in politics, a traditional duty of the aristocracy. ${ }^{10}$ In its 1892 obituary of the Duke, The Times reported that 'He was an active director of the London and NorthWestern, of the Highland, and other railways... and he was ever ready to assist in the development of ingenious ideas in machinery, mechanical appliances, and the like., ${ }^{11}$ To some he was seen as a dabbling plutocrat. The satirical magazine Punch wrote that 'he is clearly the wrong man in the wrong place on any platform except that of a steam engine. ${ }^{12}$

In 1895, his son, the 4th Duke of Sutherland ordered a new locomotive and carriages naming the locomotive Dunrobin, after his castle. One of the unique features of the locomotive was the enlarged footplate and enclosed cab with a four-person upholstered seat set high up at the back. This may be where the idea of the 3rd Duke of Sutherland enjoying riding on the footplates of trains came from. Those riding in its cab were to include King Edward VII, King George V, King George VI, King Alfonso of Spain, Kaiser Wilhelm II and Sir Winston Churchill. ${ }^{13}$ 


\section{Endnotes}

1 The National Operatic and Dramatic Association, in 1899, reported that in 1914 nearly 200 British amateur operatic societies were producing Gilbert and Sullivan works that year.

2 For the last two decades of his life W S Gilbert lived at Grim's Dyke, his house in North West London. The nearest station was Harrow and Wealdstone, a stop on the Watford to Euston line.

3 The Times, September 28, 1897.

4 Philip Scowcroft. "Railways in Music”. http://www.musicweb-international.com/railways_in_ music

5 The Era, December 31, 1871.

6 Pall Mall Gazette, January 3, 1872.

7 The Era, December 31, 1871.

8 Sunday Times cited in S Tillett and R Spencer. Forty years of Thespis scholarship. 2002. https:// www.gsarchive.net/thespis/Thespis40.pdf

9 Carolyn Williams. Gilbert and Sullivan. Gender, Genre and Parody. (New York: Columbia University Press, 2011): 52.

10 Annie Tindley. Sutherland Estate, 1850-1920. Aristocratic Decline, Estate Management and Land Reform. (Edinburgh: Edinburgh University Press, 2010): 51.

11 The Times, September 24, 1892.

12 Punch, January 26, 1878.

13 National Railway Museum. https://blog.railwaymuseum.org.uk/dunrobin-royal-engine/ 
10.5920/railways.4 